\title{
Manajemen Kebidanan Pada Ibu Bersalin Dengan Retensio Plasenta
}

Midwifery Management in Maternal Maternity with Placenta Retention

\author{
Agustin Dwi Syalfina $^{1}$, Sari Priyanti ${ }^{2}$, Dian Irawati ${ }^{3}$ \\ ${ }^{123}$ Sekolah Tinggi Ilmu Kesehatan Majapahit Mojokerto \\ agustinpipin2@gmail.com; Jln. Raya Gayaman Km.02 Mojoanyar Mojokerto
}

\begin{abstract}
ABSTRAK
Retensio plasenta merupakan kondisi perlengketan plasenta atau belum lahir lebih dari 30 menit setelah bayi lahir karena elastisitas uterus yang menurun dan kontraksi. Faktor risiko yang mempengaruhi kejadian retensio plasenta antara lain paritas, usia, jarak kehamilan, anemia, kondisi social ekonomi, rahim yang besar, Riwayat komplikasi pada kehamilan sebelumnya. Penelitian ini bertujuan untuk menggambarkan tanda gejala dan penanganan ibu bersalin dengan retensio plasenta. Penelitian ini merupakan penelitian epidemiologi deskriptif dengan pendekatan case report. Teknik pengumpulan data dengan melakukan pendampingan continue of care mulai dari kehamilan sampai dengan pemakaian kontrasepsi serta memberikan asuhan kebidanan melalui kunjungan rumah. Asuhan persalinan pada ibu dilakukan selama pendampingan di tempat praktik bidan yayuk siswatiningsih. Ny "S" mengalami komplikasi pada kala III yaitu retensio plasenta karena plasenta lebih dari 30 menit belum lahir. Penatalaksanaan yang dilakukan dengan melakukan pemasangan infus, menyuntikkan oksitosin 10 IU secara IM dam melakukan plasenta manual. Plasenta bisa dilahirkan secara manual, setelah itu bidan mengajarkan massage pada uterus kepada ibu dan keluarga untuk mengendalikan kontraksi tetap adekuat. Asuhan kebidanan yang dilakukan pada Ny " $\mathrm{S}$ " berhasil dilakukan dengan baik sehingga tidak terjadi perdarahan. Faktor risiko yang dimiliki Ny "S" yang meningkatkan kejadian retensio plasenta adalah obesitas. Petugas Kesehatan dan masyarakat diharapkan mampu mendeteksi komplikasi sedini mungkin sejak kehamilan sehingga mampu dilakukan pencegahan dengan cepat.
\end{abstract}

Kata Kunci: Manajamen Kebidanan, Bersalin, Retensio Plasenta

\begin{abstract}
Placenta retention is a condition of attachment of the placenta or not yet born more than 30 minutes after the baby is born due to decreased elasticity of the uterus and contractions. Risk factors that influence the incidence of retained placenta include parity, age, gestational distance, anemia, socioeconomic, large uterus, history of complications in previous pregnancies. The study aimed to describe the signs and symptoms and management of women giving birth with retained placenta. This study is a descriptive epidemiological study with a case report approach. Data collection techniques with continuing of care assistance from pregnancy to the use of contraception as well as providing midwifery care through home visits. Maternity care for mothers was carried out during assistance at the midwife practice of Yayuk Siswatiningsih. Mrs " $S$ " had complications in the third stage, namely retained placenta because the placenta had not been delivered for more than 30 minutes. The management is done by infusion, injecting oxytocin 10 IU IM, and performing manual placenta. The placenta can be delivered manually, after which the midwife teaches massage of the uterus to the mother and family to control contractions to remain adequate. The midwifery care carried out on Mrs. " $S$ " was successful so that there was no bleeding. Mrs "S" risk factor that increases the incidence of retained placenta is obesity. Health workers and the community are expected to be able to detect complications as early as possible since pregnancy so that prevention can be done quickly.
\end{abstract}

Keywords: Management Obstetrics, Maternity, Retention Placenta 
Agustin Dwi Syalfina, Sari Priyanti, Dian Irawati : Manajemen Kebidanan Pada Ibu Bersalin ...

\section{PENDAHULUAN}

Kematian wanita dalam usia reproduksi di seluruh dunia paling banyak dikarenakan komplikasi yang berhubungan dengan kehamilan dan persalinan. Lebih dari separuh kematian ini terjadi dalam 24 jam pertama setelah melahirkan dan dikaitkan dengan jumlah perdarahan lebih dari 500 cc disebut Haemorarghia Post Partum (HPP). Menurut WHO, dari 275.000 wanita yang meninggal setiap tahun pada masa kehamilan dan persalinan, seperempat kematian terjadi karena postpartum primer pendarahan. Dengan demikian, perdarahan pascapartum primer tetap menjadi masalah kesehatan utama karena mayoritas kematian ibu (88\%) terjadi dalam waktu empat jam setelah melahirkan meskipun persalinan sudah dalam pengelolaan manajemen aktif kala tiga persalinan (Gregory Edie HalleEkane et al., 2016).

Data kematian ibu di Indonesia juga mengalami peningkatan pada Tahun 2007 capaiannya 228/100.000 kelahiran hidup (KH) menjadi 359/100.000 KH tahun 2012. Tingginya capaian tersebut disebabkan oleh perdarahan (30,3\%), hipertensi dalam kehamilan $(27,1 \%)$, infeksi (7,3\%), penyebab lain $(35,3 \%)$ (Kemenkes RI, 2014). Angka kematian ibu (AKI) di Jawa Timur juga mengalami peningkatan seiring dengan peningkatan AKI di Indonesia adalah 83/100.000 KH pada tahun 2008 sedangkan tahun 2012 bertambah pada angka 97,43/100.000 KH. Situasi ini tidak hanya terjadi pada tingkat provinsi saja namun juga terjadi pada tingkat kabupaten. Di Kabupaten Mojokerto, capaian AKI sebesar 117/100.000 KH pada tahun 2012 yang terus meningkat sebesar 174/100.000 KH tahun 2017. Penyebab AKI di Kabupaten Mojokerto antara lain dikarenakan perdarahan pasca salin $35 \%$, pre eklamsia $10 \%$ dan penyakit penyerta seperti sepsis, penyakit jantung, gagal ginjal kronis, kanker, TBC, emboli 55\%.

Perdarahan post partum merupakan salah satu penyebab tertinggi kejadian AKI di seluruh dunia. Perdarahan post partum adalah keadaan dimana jumlah darah yang keluar setelah melahirkan baik dalam 24 jam pertama (primer) atau lebih dari 24 jam(sekunder) setelah melahirkan sebanyak lebih dari 500cc. Perdarahan yang terjadi dalam 24 jam pertama setelah melahirkan disebabkan, robekan jalan lahir, atonia uteri, retensio plasensta, sisa plasenta dan gangguan 
pembekuan darah (Yekti Satriyandari, 2017). Kematian ibu saat persalinan oleh perdarahan disebabkan oleh atonia uteri (50-60\%), retensio plasenta (16-17\%), sisa jaringan plasenta (23-24\%), laserasi jalan lahir (4-5\%), kelainan darah (0,50,8\%) (Sugi Purwanti; Yuli Trisnawati, 2015).

Perdarahan post partum karena retensio plasenta adalah kondisi dimana plasenta tertahan dalam rahim dan belum keluar selama 30 menit setelah bersalin disebabkan uterus tidak berkontraksi dengan baik. Oleh karena itu, penting untuk mengetahui keadaan tipe perdarahan mana yang terjadi dan faktor risikonya terkait. Resiko meninggal akibat perdarahan post partum tidak hanya tergantung pada jumlah kehilangan darah, tetapi juga status kesehatan wanita. Sosial ekonomi,gaya hidup, malnutrisi sebagai hal yang tak terhindarkan dan tidak dapat diubah serta kecepatan dan ketepatan penanganan mempengaruhi keberhasilan penanganan dari pasien dengan haemorarghia post partum. Oleh karena itu penting sekali melakukan upaya untuk mencegah retensio plasenta pada persalinan melalui deteksi dini komplikasi kehamilan, persalinan dan penatalaksanaan manajemen aktif kala III dengan tepat dan benar. Penelitian ini memberikan gambaran tentang tanda retensio plasenta beserta penanganan untuk mencegah perdarahan pasca salin yang bias dijadikan sumber literasi pada praktik asuhan kebidanan. Berdasarkan latar belakang diatas maka penelitian ini bertujuan untuk melakukan asuhan kebidanan pada ibu bersalin dengan retensio plasenta.

\section{METODE}

Jenis Penelitian yang digunakan oleh peneliti yaitu epidemiologi deskriptif kategori laporan kasus (case report). Responden penelitian yang digunakan adalah ibu bersalin Ny "S" usia 22 tahun. Lokasi pengambilan data di PMB Yayuk S Desa Randu Genengan Kecamatan Dlanggu Kabupaten Mojokerto. Pengambilan data tanggal 3 Maret 2020 yang dilakukan melalui tahapan pengkajian (data subyektif dan obyektif); analisis masalah yang didalamnya meliputi diagnose, masalah, kebutuhan dan tindakan segera; penatalaksanaan berisikan tentang implementasi dari rencana asuhan, rasional tindakan yang dilakukan dan hasil dari tindakan tersebut. Teknik pengambilan data dengan melakukan wawancara, observasi dan pemeriksaan fisik dengan menggunakan pedoman check list dan 
wawancara asuhan kebidanan pada ibu bersalin sesuai manajemen kebidanan varney yang di ringkas menjadi SOAP (Subyektif, Obyektif, Analisis, Penatalaksanaan). Data setelah dikumpulkan di dokumentasikan dalam bentuk laporan asuhan kebidanan pada ibu bersalin yang meliputi data subyektif dan obyektif.

HASIL

Tabel 1. Rekapitulasi Data Persalinan

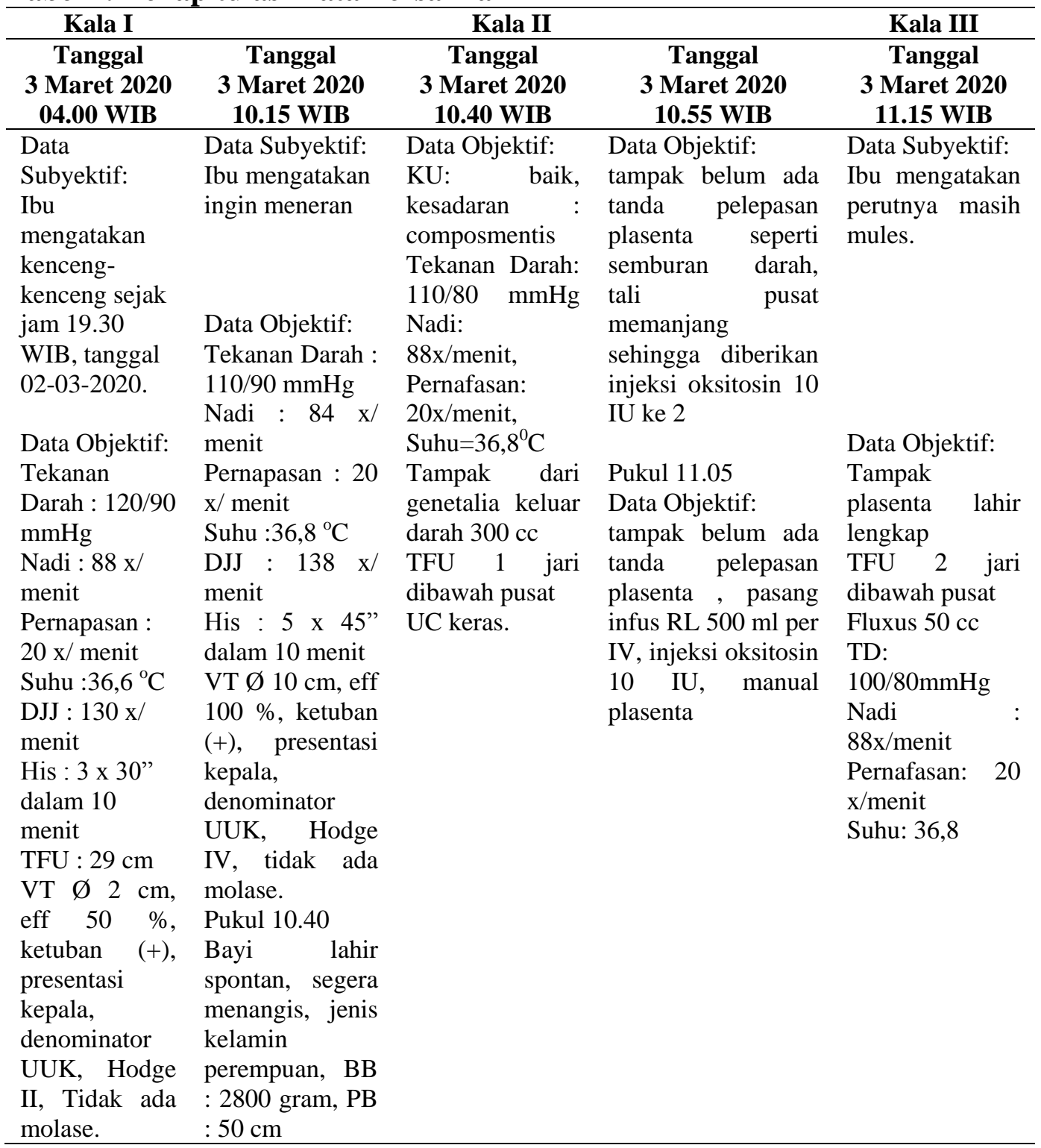

Tanggal 3 Maret 2020 pukul 04.00 WIB NY"S" datang ke PMB Yayuk mengeluh merasa kenceng-kenceng sejak pukul 19.30, HPHT= 3 Juni 2020, 
$\mathrm{HPL}=10$ Maret 2020, TB=153 cm, BB $86 \mathrm{~kg}, \mathrm{IMT}=36,7 \mathrm{~kg} / \mathrm{m}^{2}$, makan terakhir pukul 19.00 dengan menu nasi 1 piring, lauk, sayur, minum kurang lebih $600 \mathrm{cc}, 1$ gelas susu, BAK sering tiap terasa mules, pola tidur sering terbangun karena nyeri ketika kontraksi. Hasil pemeriksaan bidan keadaan umum baik, kesadaran composmentis, $\mathrm{TD}=120 / 90 \mathrm{mmHg}, \mathrm{RR}=20 \mathrm{x} / \mathrm{menit}$, suhu, $36,6{ }^{\circ} \mathrm{C}$, genetalia tampak keluar lendir dan ketuban utuh, palpasi pada abdomen yaitu TFU $29 \mathrm{~cm}$, letak kepala dan sudah masuk PAP, pemeriksaan dalam menunjukkan $\varnothing 2 \mathrm{~cm}$, eff $50 \%$, ketuban (+), presentasi kepala, denominator UUK, Hodge II, tidak ada molase, pemeriksaan laboratorium protein urine negatif. Asuhan kebidanan yang dilakukan bidan antara lain memposisikan ibu dalam posisi miring kiri, menganjurkan nafas Panjang ketika ada his, memperbolehkan ibu untuk makan dan minum, selalu memberi dukungan semangat dan motivasi, mengobservasi TTV dan CHPB.

Tanggal 3 Maret 2020 pukul 10.15 WIB, pasien mengeluh ada rasa ingin mengejan. Bidan melakukan pemeriksaan dengan hasil keadaan umum baik, kesadaran composmentis, $\mathrm{TD}=110 / 80 \mathrm{mmHg}$, nadi $84 \mathrm{x} /$ menit, pernafasan 20x/menit, suhu $36,8^{\circ} \mathrm{C}$, his 5 x 45 " dalam 10 menit, DJJ=138x/menit, VT Ø 10 $\mathrm{cm}$, eff $100 \%$, ketuban (+), presentasi kepala, denominator UUK, Hodge IV, tidak ada molase. Langkah yang dilakukan bidan yaitu mengenali adanya tanda pada ibu seperti ingin meneran, tampak ada tekanan pada rectum vagina dan perineum menonjol, tampak vulva dan sfingter ani membuka, memastikan kelengkapan alat partus, menggunakan alat perlindungan diri, meminta keluarga untuk membantu pasien menyiapkan posisi ibu untuk mengejan senyaman mungkin, mengajarkan ibu untuk mengejan yang benar ketika ada his, meminta keluarga untuk memberikan pasien minum jika tidak ada his dan selalu memberi dukungan pada ibu.

Pada pukul 10.40 bayi lahir spontan, menangis aktif, jenis kelamin perempuan, $\mathrm{BB} 2800$ gram, $\mathrm{PB}=50 \mathrm{~cm}$, pasien mengeluh perut masih terasa mules. Data obyektif meliputi keadaan umum baik, kesadaran composmentis, $\mathrm{TD}=110 / 80 \mathrm{mmHg}, \mathrm{Nadi}=88 \mathrm{x} / \mathrm{menit}$, Pernafasan $=20 \mathrm{x} / \mathrm{menit}, \quad \mathrm{Suhu}=36,8^{0} \mathrm{C}$, tampak dari genetalia keluar darah, TFU 1 jari dibawah pusat, kontraksi uterus 
keras. Bidan melakukan manajamen aktif kala III antara lain melakukan pemeriksaan tidak ada janin kembar kemudian melakukan injeksi oksitosin 10 unit secara IM, menjepit tali pusat kurang lebih 5-10 cm dari pusat dengan $2 \mathrm{klem}$ dan dilakukan pemotongan tali pusat, melakukan observasi tanda pelepasan plasenta. Pukul 10.55 tampak belum ada tanda pelepasan plasenta seperti semburan darah, tali pusat memanjang sehingga diberikan injeksi oksitosin $10 \mathrm{IU}$ ke 2 dan dilakukan pemantauan tanda pelepasan plasenta pada 15 menit yang kedua. Pukul 11.05 tampak belum ada tanda pelepasan plasenta, bidan memberikan asuhan kebidanan yaitu melakukan pemasangan infus RL $500 \mathrm{ml}$ per IV, memberikan injeksi oksitosin $10 \mathrm{IU}$, melakukan manual plasenta dengan dibantu asisten. Pukul 11.15 plasenta lahir lengkap, bidan melakukan masase uterus sambal mengecek kelengkapan plasenta dan memantau jumlah perdarahan, menganjurkan keluarga untuk memberi makan dan minum pada ibu, mengajarkan keluarga dan ibu untuk masase uterus, memberikan infus RL 500 ml drip oksitosin.

\section{PEMBAHASAN}

Retensio plasenta merupakan keadaan plasenta yang belum dilahirkan atau keterlambatan pengeluaran plasenta setelah 30 menit bayi dikeluarkan dari rahim ibu. Plasenta harus segera dapat dilahirkan dalam waktu 30 menit supaya tidak terjadi perdarahan karena plasenta yang masih melekat pada dinding uterus menghambat efektifitas kontraksi. Selain itu juga jika terjadi retensio plasenta dan dilakukan penanganan dengan pengeluran plasenta secara manual kemungkinan bisa mengakibatkan infeksi pasca salin, choriocarsinoma dan polip pada uterus (Harahap, 2016). Retensio plasenta dilihat dari penyebab meliputi retensio plasenta fungsional dan retesio plasenta patologi anatomi. Retensio plasenta fungsional karena his yang tidak adekuat sehingga plasenta tidak mampu terlepas dari dinding rahim, bentuk plasenta membranasea dan anularis, plasenta berukuran lebih kecil dari normal. Retensio plasenta tipe patalogi anatomi dikarenakan adanya kelainan dalam perlekatan plasenta yang disebut plasenta akreta, inkreta dan perkreta (Budiman, 2017).

Tanda adanya perdarahan adalah indikasi untuk segera melahirkan 
plasenta. Hal ini menunjukkan telah terjadi pelepasan sebagian dari bagian plasenta sehingga terbukanya sinus darah ketika uterus berkontraksi. Penanganan dengan cepat dan tepat dari manajemen aktif kala III sebagai cara penanganan komplikasi perdarahan (Dwi Rahmawati, 2019). Patofisiologi retensio plasenta tidak diketahui secara pasti. Namun ada 3 mekanisme utama untuk terjadinya retensio plasenta yaitu plasenta invasive yang biasanya hasil dari trauma rahim sebelumnya, hipoperfusi plasenta (berhubungan dengan remodeling arteri spiralis yang tidak lengkap dan penempelan plasenta yang dangkal) serta kontraktilitas miometrium yang tidak memadai (kegagalan kontraktilitas retroplasenta lokal) (Alessandro Favilli, Valentina Tosto, Margherita Ceccobelli, Fabio Parazzini, Massimo Franchi, 2021).

Keluhan Ny"S” datang periksa karena mengeluh perutnya terasa kencengkenceng. Persalinan merupakan proses pengeluaran janin dan plasenta yang sudah matang dan siap hidup diluar kandungan baik melalui vagina atau tindakan operatif. Tanda yang menunjukkan ibu hamil melahirkan ditunjukkan adanya kontraksi yang kuat dan durasinya teratur semakin lama semakin sering dan semakin kuat seiring dengan bertambahnya pembukaan serviks. Ibu ketika mendekati persalinan merasakan kontraksi yang biasa disebut kenceng-kenceng pada perutnya dan terasa nyeri. Kontraksi dari bagian otot uterus pada lapisan ke dua yang disebut myometrium dikarenakan peningkatan oxytocin hormone dan penurunan progresteron. Kontraksi tersebut semakin lama semakin kuat dan sering muncul sehingga mampu memberikan rangsangan kepada ibu dan sebagai kekuatan untuk mengeluarkan janin (Metti, 2016). Kontraksi tersebut memberikan rangsangan nyeri pada ibu bersalin namun rasa nyeri yang muncul memiliki perbedaan pada setiap fase pada kala I persalinan tergantung karakteristik klinis, respon fisiologis dan jalur saraf (I.Widiawati dan Legiati, 2018).

Hasil pemeriksaan menunjukkan ada pembukaan dan penipisan serviks ketika datang dan membutuhkan waktu kurang lebih 6 jam sampai dengan pembukaan maksimal dari serviks yaitu $10 \mathrm{~cm}$ serta genetalia ibu tampak keluar lendir. Dilatasi serviks merupakan pelebaran dari bibir dan saluran serviks yang diikuti juga dengan penipisan. Diameter lubang serviks membuka dari $1 \mathrm{~cm}$ 
sampai dengan $10 \mathrm{~cm}$, sedangkan penipisan serviks yang awalnya ketebalan $2 \mathrm{~cm}$ menjadi tidak teraba sama sekali. Pembukaan $10 \mathrm{~cm}$ dan serviks sudah tidak teraba sebagai tanda berakhirnya kala I dan memasuki kala II untuk mengeluarkan hasil konsepsi. Kecepatan pembukaan serviks dipengaruhi oleh kekuatan serviks dan terapi non farmakologis seperti massage pada yang memberikan rasa nyaman sehingga tidak cemas ataupun stress (Nadia dan Endarti, 2016).

Proses dilatasi serviks di bagi menjadi 2 tahap yaitu laten dan aktif. Fase laten dimana kondisi ibu bersalin dalam pembukaan 0-3 cm, fase aktif menunjukkan pembukaan serviks $4-10 \mathrm{~cm}$. Pada setiap tahapan memiliki perbedaan antara ibu primigravida dan multigravida. Lama fase laten ibu primigravida 8-10 jam dan multi gravida 6-8 jam, sedangkan proses fase aktif kurang lebih 6 jam (Kurniawati, 2017). Tanda ibu hamil telah memasuki proses persalinan ditunjukkan juga keluarnya lendir yang bercampur darah (bloody show). Lendir ini disebabkan adanya pembukaan dan pelebaran serviks, sedangkan darah karenan pecahnya pembuluh darah kapiler pada saluran serviks yang mengalami pergeseran pada saat dilatasi serviks (Nikmah, 2017).

Kala II Ny“S” berlangsung normal selama 25 menit. Kala II adalah fase pengeluaran janin dari rahim ibu yang di tandai dengan pembukaan sudah lengkap $10 \mathrm{~cm}$, kontraksi semakin sering dan kuat, ibu merasakan ingin meneran serta tampak tekanan pada anus. Ada perbedaan antara lama kala II primigravida dan multigravida yaitu 2 jam dan 1 jam. Apabila bayi lebih dari patokan waktu normal tersebut belum dilahirkan ibu sudah dikatakan persalinan lama atau kala II memanjang. Komplikasi terjadinya persalinan lama diantaranya kelelahan, infeksi, perlukaan ada jalan lahir, dehidrasi, gawat janin sampai dengan kematian bayi. Salah satu faktor penyebab terjadinya kala II memanjang adalah anemia ibu hamil (Andriani, 2016).

Lama proses persalinan $\mathrm{Ny}$ “S” kurang lebih 15 jam dimulai terasa nyeri karena kenceng sampai dengan bayi lahir. Menurut Ardhiyanti dan Susanti (2016), dikatakan persalinan lama jika proses persalinan mulai tanda awal seperti kontraksi, keluar lendir, pembukaan di rasakan pertama kali sampai dengan hasil konsepsi dikeluarkan melalui jalan lahir berlangsung lebih dari 18 jam. Persalinan 
lama menyebabkan terjadinya infeksi dan perdarahan pasca bersalin sebagai salah satu faktor risiko kematian pada ibu. Faktor maternal yang menyebabkan persalinan lama yaitu usia ibu, kontraksinya tidak adekuat/hipotonis, jumlah anak yang pernah dilahirkan sebelumnya, sedangkan faktor bayi meliputi kelainan pada sikap bayi, letak bayi, posisi dan presentasi bati, berat badan bayi, kelainan kongenital (Ardhiyanti dan Susanti, 2016).

Kala III pasien berlangsung lama, lebih dari 30 menit plasenta belum lahir. Kala III adalah fase pelepasan dan pengeluaran plasenta. Pengeluaran plasenta Ibu Primigravida dan multigravida normalnya dalam waktu kurang lebih 10 menit dan tidak lebih dari 3o menit, proses ini dihitung setelah bayi lahir. Meskipun bayi sudah lahir ibu merasakan nyeri karena kontraksi uterus, kontraksi ini berguna untuk melepaskan plasenta dari dinding rahim. Tanda adanya kontraksi setelah janin keluar dari rahim yaitu fundus uteri teraba keras, ketika plasenta sudah lepas dari dinding rahim maka tali pusat akan bertambang Panjang dan tampak ada semburan darah (E.Rahmadhayanti dan Kamtini, 2018). Penatalaksanaan untuk melahirkan plasenta dengan melakukan injeksi oxytocin 1 menit pertama setelah bayi lahir untuk merangsang kontraksi uterus, Plasenta dalam waktu 15 menit belum tampak tanda lepas dari dinding rahim maka ibu harus diberikan suntikan oxytocin $10 \mathrm{IU}$, namun 15 menit setelah pemberian oxytocin yang kedua masih belum juga lahir maka harus dilakukan manual plasenta untuk menghindari jumlah perdarahan yang banyak (lebih dari $500 \mathrm{cc}$ ) (Purwanti, 2017).

Keterlambatan uri untuk dilahirkan dalam waktu lebih dari 30 menit di namakan retensio plasenta (perlengkatan plasenta). Retensio plasenta merupakan satu penyebab haemorarghia post partum. Retensio plasenta terjadi dikarenakan plasenta memang belum lepas dari dinding uterus dan sudah lepas sebagian sehingga tampak perdarahan yang keluar dari vagina sebagai tanda plasenta harus segera dilahirkan secara manual. Plasenta yang belum terlepas atau hanya sebagian karena kontraksi yang tidak adekuat. Jika perlekatan plasenta terlalu kuat dan penempelannya sampai dengan myometrium atau dinding abdomen dinamakan plasenta akreta dan perkreta. Kondisi seperti ini tidak dianjurkan untuk dilakukan manual plasenta (F.A. Permatasari, S. Handayani, 2017). 
Faktor risiko kejadian perlengketan plasenta terdiri dari faktor maternal (usia, paritas, anemia, jarak kehamilan kurang dari 2 tahun, pendidikan), sosial ekonomi, faktor uterus (rahim yang besar) dan Riwayat komplikasi persalinan yang lalu. Hasil penelitian Riyanto (2015) menunjukkan bahwa usia, paritas dan anemia berpengaruh terhadap kejadian retensio plasenta. Usia kurang dari 20 tahun dan lebih dari 35 tahun berisiko terjadi perlengkatan plasenta karena alat reproduksi usia muda perkembangan belum sempurna dan usia tua sudah mengalami penurunan pada desidua yang mengganggu perlekatan plasenta pada rahim. Selain itu hamil pada usia tua menyebabkan kontraksi uterus kurang adekuat dan endometrium mengalami kemunduran dalam pemenuhan nutrisi untuk janin sehingga plasenta memperluas pertumbuhan dan daerah implantasi dan vili khorialis menembus sampai dengan myometrium. Ibu yang melahirkan lebih dari 2 kali meningkatkan risiko perlengkatan plasenta karena jaringan fibrosa menggantikan serat otot dalam rahim, penurunan kontraktilitas, kompresi pembuluh darah lebih sulit dan terjadilah perlengkatan pada daerah implantasi.

Dilihat dari segi usia dan paritas Ny "S" buka merupakan faktor risiko terjadinya retensio plasenta pada ibu. Retensio plasenta yang dialami Ny"S" karena IMT ibu dalam kategori obesitas. Obesitas menyebabkan distensi rahim yang terlalu besar sehingga mengurangi kekuatan kontraksi dari uterus. Lemahnya kontraksi uterus mempersulit pelepasan dari plasenta. Hasil penelitian Setyorini et al (2019) bahwa sebagian besar ibu bersalin dengan perdarahan post partum memiliki BMI dengan kategori obesitas. Ibu hamil yang obesitas memiliki rahim dengan ukuran besar, otot rahim yang meregang dan elastisitas otot uterus terganggu yang belum bisa kembali seperti sebelum hamil sehingga uterus tidak mampu kontraksi dengan adekuat dan menyebabkan plasenta susah terlepas dan terjadi perdarahan.

\section{SIMPULAN}

Asuhan Kebidanan pada persalinan Ny"S" dengan retensi plasenta ditandai dengan plasenta tidak menunjukkan tanda pelepasan setelah 30 menit dan tampak pengeluaran darah aktif sehingga diberikan penatalaksanaan pemberian injeksi oksitosin 10 IU dan dilakukan observasi selama 15 menit. Setelah 15 menit 
pertama masih belum menunjukkan tanda pelepasan plasenta di berikan oksitosin 10 IU ke dua, pasang infus drip oksitosin, melakukan kelahiran plasenta secara manual untuk mencegah perdarahan dan penatalaksanaan ini berhasil dilakukan sehingga plasenta bisa dilahirkan dan perdarahan dapat dicegah.

\section{UCAPAN TERIMA KASIH}

Peneliti mengucapkan rasa terima kasih kami kepada ketua Sekolah Tinggi Ilmu Kesehatan Majapahit Mojokerto dan ketua LPPM atas perijinan terhadap penelitian serta Yayuk Siswatiningsih atas ijin untuk pengambilan data dan pendampingan kepada peneliti selama melakukan asuhan kebidanan, rekan sejawat dan tim peneliti yang memberi bantuan dan dukungan demi terselesaikan penelitian.

\section{DAFTAR PUSTAKA}

Alessandro Favilli, Valentina Tosto, Margherita Ceccobelli, Fabio Parazzini, Massimo Franchi, V. B. \& S. G. (2021) 'Risk factors for non-adherent retained placenta after vaginal delivery: a systematic review', $B M C$ Pregnancy and Childbirth, 21(268), pp. 2-13.

Andriani, R. A. D. (2016) 'Hubungan Anemia pada Kehamilan Dengan Inpartu Kala II Lama di BPM Ny. Suhariyati Surabaya', Jurnal Ilmiah Kesehatan, 9(1), pp. 52-57.

Budiman, D. M. (2017) 'Perdarahan Post Partum Dini e.c Retensio Plasenta', Jurnal Medula Unila, 7(3), pp. 6-10.

D. Setyorini, I.Cahyono, N. H. (2019) 'Karakteristik Ibu yangBerisiko Mengalami Perdarahan Pasca Partum', in Prosiding Seminar Nasional Kesehatan. Surabaya: PoltekesDepkes Surabaya, pp. 17-20.

Dwi Rahmawati, S. J. (2019) 'Hubungan Antara Paritas Dan Retensio Plasenta Dengan Kejadian Perdarahan Post Partum Primer Di Rumah Sakit Baiturrahim Jambi Tahun 2015', Jurnal Ilmiah Umum Dan Kesehatan Aisyiah, 4(1), pp. 64-73.

E.Rahmadhayanti, D. I. and Kamtini (2018) 'Pengaruh Pemberian Rangsangan Puting Susu Terhadap Lama Kala Iii Pada Ibu Bersalin', Jurnal Ilmiah Multi Science Kesehatan, 9(2), pp. 188-197.

F.A. Permatasari, S. Handayani, E. R. (2017) 'FaktorFaktor yang Berhubungan dengan Kejadian Perlengketan Plasenta (Retensio Placenta) di Rumah Sakit Islam Jakarta Cempaka Putih: Sebuah Studi Kasus Kontrol', Jurnal ARKESMAS, 2(1), pp. 102-108.

Gregory Edie Halle-Ekane, F. K. E. et al. (2016) 'Prevalence and Risk Factors of Primary Postpartum Hemorrhage after Vaginal Deliveries in the Bonassama District Hospital, Cameroon', International Journal of Tropical Disease \& Health, 13(2), pp. 1-12. 
Harahap, U. M. (2016) 'Hubungan Usia Dengan Kejadian Retensio Plasenta Pada Ibu Bersalin Di Rumah Sakit Daerah Kolonel Abundjani Tahun 2015-2016', Jurnal Kesehatan dan Sains Terapan STIKes Merangin, 2(2), pp. 12-21.

I.Widiawati, T. L. (2018) 'Mengenal Nyeri Persalinan Pada Primipara dan Multipara', Jurnal Bimtas, 2(1), pp. 42-48.

Kemenkes RI (2014) Profil Kesehatan Indonesia. Jakarta: Kementerian Kesehatan RI.

Kurniawati, D. (2017) 'Manajemen Intervensi Fase Laten Ke Fase Aktif Pada Kemajuan Persalinan', Jurnal Keperawatan dan Pemikiran Ilmiah, 3(4), pp. 27-34.

Metti, D. (2016) 'Pengatahuan Ibu Hamil Primigravida Tentang Tanda-Tanda Persalinan Di Wilayah Lampung Utara', Jurnal Keperawatan, XII(2), pp. $228-232$.

Nadia, A. . endarti (2016) 'Pengaruh Massage Counter-Pressure Terhadap Adaptasi Nyeri Persalinan Kala 1 Dan Kecepatan Pembukaan Pada Ibu Bersalin', Jurnal Ilmiah Kesehatan, 8(2).

Nikmah, K. (2017) 'Hubungan Posisi Persalinan Dengan Kemajuan Persalinan Kala 1 Fase Aktif Pada Primigravida', Jurnal Midpro, 9(2), pp. 50-55.

Purwanti, S. (2017) 'Pengaruh Waktu Pemberian Oxytocin Dengan Lama Pengeluaran Plasenta Pada Kala Iii Persalinan', Jurnal Publikasi Kebidanan Akbid YLPP Purwokerto, 8(1), pp. 112-120.

Riyanto (2015) 'Faktor Risiko Kejadian Retensio Plasenta Pada Ibu Bersalin Di Rsud Dr. H. Bob Bazar, SKM Kalianda', Jurnal Kesehatan Metro Sai Wawai, 8(1), pp. 38-44.

Sugi Purwanti; Yuli Trisnawati (2015) 'Determinan Faktor Penyebab Kejadian Perdarahan Post Partum Karena Atonia Uteri', Jurnal Ilmiah Kebidanan, 6(1), pp. 97-107.

Y.Ardhiyanti, S. S. (2016) 'Faktor Ibu yang Berhubungan dengan Kejadian Persalinan Lama di RSUD Arifin Achmad Pekanbaru', Jurnal Kesehatan Komunitas, 3(2), pp. 83-87.

Yekti Satriyandari, N. R. H. (2017) 'Faktor-Faktor Yang Mempengaruhikejadian Perdarahan Postpartum', Journal of Health Studies, 1(1), pp. 49-64.

\begin{tabular}{|l|l|}
\hline Submission & $08-03-2021$ \\
\hline Review & $26-03-2021$ \\
\hline Accepted & $19-09-2021$ \\
\hline Publish & $29-10-2021$ \\
\hline DOI & $10.29241 /$ jmk.v7i2.614 \\
\hline Sinta Level & 3 (Tiga) \\
\hline
\end{tabular}

